University of Nebraska - Lincoln

DigitalCommons@University of Nebraska - Lincoln

To Improve the Academy

Professional and Organizational Development Network in Higher Education

1994

The Implication of Cultural Diversity in American Schools

Johnson A. Afolayan

Follow this and additional works at: https://digitalcommons.unl.edu/podimproveacad

Part of the Higher Education Administration Commons

Afolayan, Johnson A., "The Implication of Cultural Diversity in American Schools" (1994). To Improve the Academy. 299.

https://digitalcommons.unl.edu/podimproveacad/299

This Article is brought to you for free and open access by the Professional and Organizational Development Network in Higher Education at DigitalCommons@University of Nebraska - Lincoln. It has been accepted for inclusion in To Improve the Academy by an authorized administrator of DigitalCommons@University of Nebraska - Lincoln. 


\section{The Implication of Cultural Diversity in American Schools}

\section{Johnson A. Afolayan}

Moorhead State University

The purpose of this article is to analyze the major factors responsible for the cultural diversity in America and their implications for professional educators. These factors include immigration, communication, linguistic diversity, cultural values, and desegregation. While some educators look to the demographics of the new student population, others consider historical clues as a method of understanding American diversity. Statistics about school achievement and dropout and graduation rates show the disparity among the ethnic groups. The new immigrants and ethnic groups may experience conflict as a result of cultural attitudes of teachers and peers. Individuals cannot be understood unless they are seen against the cultural history from which they have come and in terms of the situation in which they currently live. Because of the diversity in the American population, educators need to be sensitive to the cultural elements that may affect students' performance and self-esteem.

\section{The Implications of Cultural Diversity in American Schools}

There is an essential need for sensitive educators in the classrooms. The diversity of the population of educational institutions will continue to increase as we face the last decade of this century. The pluralism and interdependent reality of schools cannot be ignored. The success of schools and educators depends on the understanding that 
embraces racial, gender, cultural, and attitudinal differences. Any of the demographic differences can be used as an agent of educational disadvantage.

The purpose of this article is to analyze the educational implications of the cultural diversity in American schools. These implications include immigration, communication, linguistic diversity, cultural values, and desegregation.

\section{Immigration}

Americans have always believed that education can be a transformational success story and can also offer a way out of poverty. This belief has been legitimated by the experience of two centuries of immigration (Bennett, 1988). The first Europeans settled along the east and west coasts during the 17th century. Ten million Native Americans were displaced by these settlers. In the 1600 s, African peoples were brought to America by the Europeans, and by the mid-1800s Chinese began to migrate to America. Between 1900 and 1920 immigrants came mainly from central and southern Europe. The mid-1900s brought an internal migration of Blacks from the rural South to the urban North.

While some educators perceive a newly diverse student population, others look back to history for clues in dealing with diversity (Shane, 1990). Bennett (1988) stated that minorities already make up $28 \%$ of the school-age population. The impact of current and future immigration is almost paled by the flood of people that entered America between 1900 and 1910. At that time, 57.8\% of pupils in 37 selected large cities were either foreign born or had immigrant parents.

The ethnicity of the current migrating people is different. The 1909 group was mainly of European descent and unskilled. The present immigration wave consists primarily of Hispanic and Asian cultures (Gough, 1988). In 1985, each group commanded $40 \%$ of the immigrants. There is conflict as to which ethnic group is fastest growing. Lee and Rong (1988) state that the Asian American population is increasing most rapidly and that no other group boasts of such a highly educated segment. Campbell, Cunningham, Nystrand, and 


\begin{tabular}{|l|r|r|r|r|r|r|}
\hline \multicolumn{7}{|c|}{ TABLE 1 } \\
\hline \multicolumn{7}{|c|}{ Pre-Primary Enrollment (3-5 years old), 1985-1988 } \\
\hline Groups & \multicolumn{1}{|c|}{1985} & \multicolumn{1}{|c|}{ Rate \% } & \multicolumn{1}{|c|}{1987} & Rate \% & \multicolumn{1}{c|}{1988} & \multicolumn{1}{|c|}{ Rate \% } \\
\hline White & 4,430 & 54.7 & 478 & 54.1 & 4,891 & 55.4 \\
Black & 758 & 55.8 & 893 & 54.2 & 814 & 48.2 \\
Hispanic & 406 & 43.3 & 587 & 45.5 & 544 & 44.2 \\
\hline
\end{tabular}

Usdan (1990) argue that the Hispanic population is burgeoning (see Table 1).

The youth of the latest immigration wave is probably its most important characteristic. While the median age of the U.S. population is 32.1, the Hmong median age is 13; Cambodian, 18; Laotian, 19; and Vietnamese, 21. Of the Hispanic immigrants, the median age for Mexicans is 23; it is 27 for Central Americans; and 39 for Cubans. These statistics can be correlated with birthrates. While Americans have an average of 1.7 children, African Americans average 2.4 children; Hmong, 11.9 children; Cambodians, 7.4; Vietnamese, 3.4; and Mexican Americans, 2.9 children. Statisticians, when using the above data, are able to project that by the year 2050 , the total population of the United States will be $60 \%$ White, $16 \%$ Black, $15 \%$ Hispanic, and 10\% Asian (Kellogg, 1988).

\section{Educational Statistics of Ethnic Groups}

In the past, American classrooms have been composed of the rich, the poor, and the in-between. The students' parentage has been both educated and unskilled. Teachers have taught well through war, depression, civil unrest, and times of prosperity. The diversity which the educators face today is one that differs only by degree and detail (Bennett, 1988).

Between 1982 and 1987, the number of students from all ethnic and racial groups who possessed high school diplomas doubled (Lewis, 1989). One quarter of all students taking the SAT were ethnic minorities. The scores earned on this test have risen for these ethnic groups during the last 10 years. While Whites raised their average 


\begin{tabular}{|c|c|c|c|c|c|}
\hline \multicolumn{6}{|c|}{$\begin{array}{c}\text { TABLE } 2 \\
\text { American College Testing for College Bound Students, } \\
1984-1988\end{array}$} \\
\hline Particjpants & 1984 & 1985 & 1986 & 1987 & 1988 \\
\hline $\begin{array}{l}\text { White } \\
\text { Black }\end{array}$ & $\begin{array}{l}46 \% \\
82 \% \\
\end{array}$ & \begin{tabular}{|l|}
$46 \%$ \\
$82 \%$ \\
\end{tabular} & $\begin{array}{l}46 \% \\
82 \% \\
\end{array}$ & $\begin{array}{r}46 \% \\
81 \% \\
\end{array}$ & $\begin{array}{l}46 \% \\
81 \% \\
\end{array}$ \\
\hline \multicolumn{6}{|c|}{ Source: U. S. Bureau of Census } \\
\hline
\end{tabular}

scores on the verbal portion of the exam by two points, African American students raised their verbal scores by 21 points; Asian Americans raised their scores by 13 points; and Hispanics by 13 points. On the mathematics portion of the test, Caucasians' scores increased nine points; African Americans' scores, 28 points; Asian Americans' scores, 14 points; and Hispanics' scores, 20 points (Washington Windmill, 1990) (see Table 2).

Dropout rates reflect both good and bad news for minorities. The Asian Americans have the lowest dropout rate of all ethnic groups with only the Vietnamese falling below the Whites' dropout rate (Lee \& Rong, 1988). The dropout rate among African American students is also declining, making the difference between the African American and White figures only $2 \%$ now, compared to $12 \% 20$ years ago (Lewis, 1989). However, Hispanics continue to have an appalling dropout rate. At $35.7 \%$, this is almost triple that of Whites and more than double the dropout rate for African American students. Education Secretary Lauro Cavazos, himself of Hispanic origin, regarded the situation as a national tragedy.

Ethnic minorities are usually overrepresented in disability groups. According to the Office for Civil Rights, in the school year 1986-87, minority students made up $30 \%$ of all public school students but accounted for $42 \%$ of educable mentally retarded (EMR) students, $40 \%$ of trainable mentally retarded (TMR), and $35 \%$ of those seriously emotionally disturbed. These uneven statistics are often blamed on cultural biases (Washington Report, 1988). Those who adhere to the multicultural educational paradigm of cultural deprivation (Banks, 1988) must find confirmation in these statistics. Thus, programs like Head Start receive federal funding. President Bush transmitted legis- 
lation that increased Head Start funding for the fiscal year 1990 by $\$ 250$ million.

Asian Americans, conversely, are at the other end of the scale when it comes to learning disability groups. In 1984, the percentage of Asian Americans in such groups was 1.6, as compared to 4.2 for Whites.

College graduation rates also show disparity among ethnic groups. In 1980, $17 \%$ of all white males age 25 and over had finished college. Thirty-two percent of all Asian Americans had earned higher education degrees (Lee \& Rong, 1988). However, 1989 found that while all higher education enrollment was up, especially for women, degrees earned by African American men had decreased. The number of African American women in college increased from 563,000 to 645,000 , while the number of African American men on campus fell by 40,000 to 436,000 (Washington Windmill, 1989).

Statistics can be helpful only when they provide the basis for careful thought, review, and evaluation. Now, I will present some of the factors and educational paradigms that may account for these figures.

\section{Education and Linguistic Diversity}

When one speaks of communication in a culturally diverse society, the prevalent thought is that of language differences. In fact, some educators and administrators attribute poor achievement by ethnic pupils strictly to an inability to function in a language that is not their native tongue. Thus, we have the language paradigm (Banks, 1988).

Language is a primary obstacle to communication. In California alone, more than 70 languages are represented in the schools (Olsen, 1988). Through American history, immigrants have brought their native tongues, but those languages had common characteristics like Latin roots and the Roman alphabet. Spanish is one of them. However, the native tongues brought by the recent influx of Asians bear little resemblance to the English language. The sentence structure is foreign, as are the alphabetic letters used. The Haitians only developed a 
written language half a century ago, and only within the last 30 years have the Hmong begun to write in their language (Kellogg, 1988).

Little or no English is usually spoken in the homes of the immigrants. A child may not find his or her home a suitable place to rehearse his or her infant English skills. The burden remains upon the school (First, 1988). An underfunded inner-city school may often face the paramount task of communicating with students of 40 or 50 different languages. When the standard English as a Second Language (ESL) programs came up short, a new program "English Plus" was developed by the League of United Latin American Citizens. This system shows respect for a student's primary language and culture (First, 1988). This thinking combines the Language Paradigm with that of the Cultural Differences Paradigm and provides for programs that incorporate and integrate cultural practices and ethnic content into the mainstream curriculum (Banks, 1988). The combination of these paradigms seems to work better than a strictly bilingual approach. Alicia Coro, Director of Bilingual Programs for the Office of Education, vowed not to enroll her own children in a traditional bilingual education program. She defends the Republican administration's plan to liberalize the federal bilingual education law so that school systems, at their discretion, can use money for nontraditional approaches to learning (Washington Report, 1988).

One paradox of our society is that while we are emphasizing the need to study foreign languages in the schools, particularly at the high school level, we are not cultivating the natural language resources of our own multiethnic children. These students, when forced to communicate and compete in English, often lose the literacy of their own native tongues and, in turn, all their cultural norms.

\section{Cultural Communications}

In the schools and classrooms in which a student's culture is viewed as a rich and valuable resource, there is an exciting added dimension to the educational experience. Communication reaches limitless possibilities. Difference is perceived with respect. Cultural distinctions should not interfere with character development, but rather, enhance students' values. 
Cultural differences do account for varied learning styles and may affect classroom performance. Young immigrants may experience conflict as a result of cultural misunderstandings. For example, in a California classroom, a Cambodian child became hysterical during a lively spelling lesson. Her teacher was playing "Hangman" with the spelling words, and the little girl was reliving the haunting scene of her father's execution (Olsen, 1988). One Chinese father beat his daughter and forced her to do her homework twice each night. She had brought home a report card with three "S's," and since the father knew that the school grading system began with " $A$ " and progressed downward in deficiency, he thought his daughter had performed horribly (Olsen, 1988).

Although teachers cannot be expected to learn everything about every culture, they should be sensitive to children and have a desire to be a positive, nonthreatening influence. An effective teacher will be motivated to research the cultural norms her children bring into the classroom so that she may communicate effectively. Crossed fingers, a sign of good luck used by native-born Americans, is an obscene gesture in Southeast Asia (First, 1988). Motioning a person to come by beckoning with an index finger is an insult to Asians. White means mourning in Vietnam and China, and an owl means death (Yao, 1988).

The way in which a child receives family support in education is critical. Those of multicultural backgrounds who learn to communicate well in America often feel the weight of the whole family group. They must do well. Immigrant parents often do not understand the new culture of which their children want to become a part-a culture where ideas are questioned and extracurricular activities are applauded (Divoky, 1988). Asian parents are hesitant to challenge a teacher's authority, and parent-teacher conferences are considered disrespectful (Yao, 1988). These cultural communications and expectations should be shared at teacher seminars and conferences.

Thomas Jefferson's definition of education included moral and intellectual improvement. The American people, according to a 1984 Gallup Poll, still expect the schools to aid students in developing reliable standards of right and wrong (Bennett, 1988). Schools do provide moral education. This morality is most often in unwritten codes. It is seen in the way teachers treat minority students, the 
handicapped, and those others that are part of diverse groups. Teachers may take a direct approach to the subject or may choose indirect approaches such as values clarification (Benninga, 1988). Former Secretary Bennett (1988) takes the more direct approach. He observed that several lessons may be learned from classic literature. When we want to teach our children to respect the rights of others, we should have them read the Declaration of Independence, the Gettysburg Address, and Reverend Dr. Martin Luther King's Letter from the Birmingham City Jail. No matter what approach the teacher chooses, communication among multiethnic groups can extend beyond cultural boundaries when positive values are taught and exemplified.

\section{School Desegregation}

The Supreme Court's 1954 Brown v. Board of Education decision finally mandated equal access to education. However, not all desegregation provided equality and, in fact, often perpetuated discrimination. When one small rural school was desegregated, the African American students, who were perceived by their white teachers as having low ability, were placed in separate classrooms and labeled as educationally impaired (Goetz \& Breneman, 1988). The African American parents felt the loss of sharing with their children the African American cultural heritage and traditional values. An integrated classroom goes beyond a desegregated one. It involves not only addressing numbers of multiethnic students, but also attempting to portray this diversity in its staff and curriculum.

The Radical Paradigm portrays an opposite view of communication among ethnic groups. This theory says that schools cannot free victimized cultural groups because the schools support such behaviors. A recent ethnographic study of a junior high school showed that although students came to the school with hopeful visions of the future, the school, in actuality, did not show them how to handle life's experiences. Instead, the school made them subordinate to its social class position (Grant, 1988). 


\section{Educational Implications}

As society moves ahead, some citizens are isolated and left behind, in some cases by choice, but for the most part, by the deliberate intentions of those possessing political and economic power. The resulting disadvantaged groups are found frequently among the ethnic minority groups. Their lives are limited by poverty, insecurity, lack of education, and social changes. All ethnic minority groups - African American, Appalachian White, Puerto Rican, American Indian, Cuban, Mexican-American, and other new immigrants - find themselves still bound by the status of their social class. Their search for more satisfactory living conditions, better jobs, and improved education for their children has frequently resulted in economic problems.

Education is perceived to be the only way to escape poverty. Therefore, the major emphasis is concentrated on educational goals. The Johnson Administration allocated federal funds to improve education for the poor children in order to give them the opportunity to escape future deprivation and misery. President Johnson said, "With education, instead of being condemned to poverty and idleness, young Americans can learn the skills to find a job and provide for a family" (Jeffrey, 1978, p. 3).

Rippa (1984) gave a typical analysis of the problems and the cultural incompatibility of the disadvantaged in our contemporary society. The obvious implication of such a view was that poor people needed help. They needed to change their values, habits, and their impoverished culture. Their family structure was unstable, and family members were unable to communicate in a normal fashion. The children had become the victims of the dysfunctional situation because they lacked the toys, physical surroundings, and the attention that were available to the middle-class family children. No wonder the typical culturally different children have been disadvantaged by the time they reach school. Not only did they lack the basic life experiences needed for learning, but also they missed the important awareness of schooling.

For a person to put forth the effort to learn and to be actively involved in it, that person must perceive the learning task as significant and worth doing. As people attempt to learn, they must recognize that 
they are making progress and that they are becoming successful in doing what they have undertaken. They should obtain satisfaction from this success. Education must be recognized by students as a means to help them deal with life, and the curriculum must be designed to serve this purpose (Tyler \& Matthews, 1971).

In discovering all these realities, a teacher learns that individuals cannot be understood unless they are seen against the history from which they have come and in terms of the situation in which they currently live. In a good atmosphere a child can catch the excitement of new things, new ideas, and answers to some confusing and troublesome thoughts. Schools can be a place for making discoveries, for learning, and for satisfying one's curiosity about all kinds of things. Above all, it must be a place where important people care about, respect, and help children feel worthy and accepted (Hamlin et al., 1967).

Multicultural education means educating everyone in a way that promotes equality, unity, acceptance, and understanding so that each individual can develop a positive self-image to help him or her have an equal opportunity for success. Multicultural includes everyone, whether Black, White, rich, poor, handicapped, male, female, Alabamian, Californian - everyone is multicultural in the fact that we all have differences. Because students are so diverse, it is the job of the educators to provide each with an equal opportunity for a good education. The teacher has the greatest opportunity to help in achieving this.

\section{References}

Aronowitz, D., \& Giroux, H. (1988). Schooling, culture, and literacy in the age of broken dreams: A review of Bloom and Hirsh. Harvard Educational Review, 58, 172-194.

Banks, J. A. (1988). Multiethnic education. Boston: Allyn and Bacon.

Banks, J. A., \& Banks, C. A. (1989). Multicultural education issues and perspectives. Boston: Allyn and Bacon.

Bennett, W. (1988). American education: Making it work. Washington, DC: U.S. Department of Education.

Benninga, J. S. (1988). An emerging synthesis in moral education. Phi Delta Kappan, 69, 415-418. 
Bush, G. (1989, November 14). Remarks by the President proclaiming American education week. Washington, DC: U.S. Government Printing Office.

Campbell, R. F., Cunningham, L. L., Nystrand, R. O., \& Usdan, M. D. (1990). The organization and control of American schools. Ohio: Merrill.

Divoky, D. (1988). The model minority goes to school. Phi Delta Kappan, 70, 219-222.

First, J. M. (1988). Immigrant students in U.S. public schools: Challenges with solutions. Phi Delta Kappan, 70, 205-210.

Ginsburg, H. (1972). The myth of the deprived child. Englewood Cliffs, NJ: Prentice-Hall.

Goetz, J. P., \& Breneman, E. A. R. (1988). Desegregation and black students' experiences in two rural southern elementary schools. The Elementary School Journal, 5, 489-502.

Gough, P. B. (1988). Coping with a flood. Phi Delta Kappan, 70, 186.

Grant, C. A. (1988). The persistent significance of race in schooling. The Elementary School Journal, 88, 561-568.

Hamlin, R., Mukerji, R., \& Yonemura, M. (1967). Schools for the young disadvantaged children. New York: Teachers College Press.

Hickerson, N. (1966). Education for alienation. Englewood Cliffs, NJ: Prentice-Hall.

Jeffrey, J. R. (1978). Education for children of the poor. Columbus, OH: Ohio State University.

Kellogg, J. B. (1988). Forces of change. Phi Delta Kappan, 70, 199-204.

Lee, E. S., \& Rong, X. (1988). The educational and economic achievement of Asian Americans. The Elementary School Journal, 88, 545-560.

Lewis, A. C. (1989, December). Washington news. The Education Digest, 55, 68-69.

Moore, H. A. (1988). Effects of gender, ethnicity, and school equity on students' leadership behaviors in a group game. The Elementary School Journal, 88, 515-528.

Olsen, L. (1988). Crossing the schoolhouse border: Immigrant children in California. Phi Delta Kappan, 70, 211-218.

Ornstein, A. C., \& Vairo, P. (1969). How to teach disadvantaged youth. New York: McKay.

Rippa, A. S. (1984). Education in a free society. New York: Longman.

Shane, H. G. (1990, January). Educated foresight for the 1990s. The Education Digest, 3.

Tyler, R., \& Matthew, H. (Eds.). (1971). Functional education for disadvantaged youth. New York: Committee for Economic Development.

Washington Report. (1988, February). Director of bilingual education disparages traditional bilingual programs. The American School Board Journal, 175, 42.

Washington Report. (1988, April). Minorities overrepresented in disability groups. The American School Board Journal, 175, 65.

Washington Windmill. (1989, May). College enrollment of black men is falling. The Executive Educator, 11, 32. 
Washington Windmill. (1990, January). S.A.T. scores remain unchanged. The Executive Educator, 12, 34.

Yao, E. L. (1988). Working effectively with Asian immigrant parents. Phi Delta Kappan, 70, 223-225. 